http://dx.doi.org/10.12775/szhf.2015.038

Pawee Rzewuski

UNIWERSYTET WARSZAWSKI, WARSZAWA

GENZYP@GMAIL.COM

\title{
Wizja dziejowej roli Polski w Kazaniach Jana Hempla
}

\section{Wstęp}

Myśl Jana Hempla wydaje się dziś zupełnie zapomniana. Warto jednak poznać jego dorobek ze względów historycznych, ponieważ Jan Hempel, zwany również „Janem Bożym”, cieszył się w swoim czasie pewnym autorytetem wśród polskich intelektualistów, a jego koncepcje trafiały do szerokiego grona odbiorców. Nie był postacią anonimową i można powiedzieć, że - chociaż nie odgrywał kluczowej roli - na pewno funkcjonował w intelektualnym krajobrazie Polski w okresie zaborów.

W tekście odnoszę się do koncepcji Hempla z dwóch najważniejszych prac okresu anarchistycznego, czyli z Kazań polskich ${ }^{1}$ oraz - w mniejszym stopniu - z Kazań piastowych ${ }^{2}$.

Wybór został podyktowany przede wszystkim tym, że właśnie w tych dwóch pismach najwyraźniej ujawniają się główne inspiracje Jana Hempla: polska tradycja romantyczna, szczególnie w jej mesjanistycznej odsłonie.

\footnotetext{
${ }^{1}$ J. Hempel, Kazania polskie, Toledo 1907.

2 J. Hempel, Kazania piastowe, Bielsk 1912.
} 
Autorem, który podjął się gruntownej analizy całej twórczość Jana Hempla, był Jan Szmyd ${ }^{3}$. W swojej pracy skupił się on jednak przede wszystkim na podobieństwie myśli filozofa do koncepcji znanych z etyki hinduskiej oraz niemieckiej tradycji filozoficznej (Nietzsche, Hegel oraz Kant). W interpretacji dorobku Hempla Szmyd nie akcentował wizji roli narodu polskiego w historia świata. Badacz wykazał wprawdzie, że autor Kazań stworzył własny system etyczny zwany „etyką polską”, która wywodziła się - jak to określił sam Hempel - z „prehistorii myśli polskiej”, czyli czasów przedchrześcijańskich, nie uwypuklił jednak wątków uprzywilejowanego miejsca Polaków, które są kluczowe dla zrozumienia koncepcji Hempla. Wydaje się, że Szmyd dostrzegał uniwersalizm jego myśli ${ }^{4}$, ale nie zauważał jawnie nacjonalistycznych i szowinistycznych pomysłów. W moim tekście pragnę skupić się właśnie na tych wątkach myśli „Jana Bożego"

\section{Jan Hempel. Rys biograficzny}

Jan Hempel urodził się w maju 1877 roku w domu agronoma Józefa Hempla. Od 1895 roku wskutek różnic światopoglądowych zerwał kontakt z rodziną i samodzielnie zaczął studiować filozofię oraz historię. Przez kilka następnych lat pracował na różnych posadach przy budowie kolei wschodniochińskiej, a następnie w Japonii, Indiach i we Włoszech. Od roku 1904 przebywał w Brazylii, gdzie piastował posadę polskiego nauczyciela w szkole dla dzieci emigrantów. W tym czasie po raz pierwszy bardzo wyraźnie zaakcentował antyszlacheckie i antyklerykalne poglądy. Swoje teorie społeczne wykładał w czasopiśmie „Polak w Brazylii”. Posadę stracił wskutek konfliktu z wydawcą, który nie akceptował publikowanych przez Hempla treści.

Właśnie na ten pierwszy okres w twórczości Jana Hempla przypada największy wpływ idei polskiego romantyzmu, w szczególności Ksiąg narodu polskiego i pielgrzymstwa polskiego Mickiewicza, które zainspirowały go do

\footnotetext{
${ }^{3}$ J. Szmyd, Jan Hempel - idee i wartości, Warszawa 1975.

${ }^{4}$ Tamże, s. 143.

${ }^{5}$ Istotną pracą z punktu widzenia analizy źródeł myśli okresu anarchistycznego jest następujący artykuł: J. Szmyd, Etyka polska. Z wczesnych poglądów etycznych Jana Hempla, „Etyka”, 1973, nr 12, s. 95-123. W owym artykule autor skupia się na analizie etycznych zagadnień koncepcji Hempla. Nacisk interpretacyjny położony jest na Kazania piastowe oraz na rekonstrukcję zagadnień etyki, nie zaś na analizę relacji między człowiekiem a Bogiem.
} 
napisania Kazań polskich. W tym czasie przebywał już w Paryżu, gdzie rozpoczął bardziej wnikliwe studia filozoficzne i jednocześnie zbliżył się do kół anarchistyczno-syndykalistycznych. W roku 1912 wydał kontynuację swojej poprzedniej pracy, czyli Kazania piastowe.

W kolejnych latach coraz bardziej oddalał się od myśli anarchistycznej, a zbliżał się do myśli socjalistycznej, skupionej jednak przede wszystkim na bardzo radykalnym antyklerykalizmie. Od 1919 roku należał do PPS-Lewicy i coraz bardziej w swoich poglądach się radykalizował, aż wreszcie w 1921 wstąpił w szeregi Komunistycznej Partii Robotniczej Polskiej.

W tym okresie porzucił już zupełnie mesjanistyczne przekonania i zdeklarował się jako marksista-materialista. Na przełomie lat dwudziestych i trzydziestych razem z Aleksandrem Watem i Władysławem Broniewskim redagował „Miesięcznik Literacki”. W wyniku konfliktu z władzą polską latem 1932 roku uciekł do ZSRR, gdzie aktywnie propagował idee komunizmu, redagując polskojęzyczne czasopismo „Kultura Mas”. Został rozstrzelany w ramach wielkiej czystki 19 stycznia 1937 roku.

\section{Inspiracje okresu anarchistycznego}

Autorów, których myśl wpłynęła na kształt Kazań, można podzielić na dwie grupy. W pierwszej znajdą się ci, do których Hempel bezpośrednio odwoływał się i przyznawał się do korzystania z ich spuścizny; w drugiej - ci, z których pism niewątpliwie czerpał informacje, ale starał się ukryć tę inspirację.

Do pierwszej grupy należą polscy romantycy, szczególnie Adam Mickiewicz, którego Księgi narodu polskiego i pielgrzymstwa polskiego były bezpośrednią inspiracją dla myśli Hempla. Starał się przedstawić samego siebie jako spadkobiercę myśli Mickiewicza, co wydaje się o tyle nieuzasadnione, że założenia jego koncepcji są $\mathrm{w}$ dużym stopniu sprzeczne $\mathrm{z}$ poglądami głoszonymi przez autora Dziadów. Pierwsze z jego dzieł powstało podczas emigracji do Ameryki Południowej i było skierowane do mieszkających tam Polaków. Użycie słowa Kazania w tytule mogło być nawet nawiązaniem do Kazań sejmowych Piotra Skargi. Wskazują na to podobne intencje obu autorów - kazania Hempla i Skargi miały służyć naprawie Polski.

W koncepcji Mickiewicza Polska miała być Chrystusem narodów. Polska jest silna i miła Bogu właśnie przez ofiarę, jaką ponosi. Według Mickiewi- 
cza Chrystus przyniósł światu etykę, zgodnie z którą cierpienie jest czynnikiem uświęcającym. Kiedy Francja, Anglia i Niemcy odrzuciły Boga na rzecz bożków, jedynie Polacy pozostali wierni Chrystusowi ${ }^{6}$. Siłą Polaków jest wytrwałość i to właśnie dlatego odegrają oni istotną rolę w zbawieniu świata. Tymczasem koncepcja Jana Hempla jest diametralnie inna. Polska przestała istnieć właśnie dlatego, że stosowała się do nauk Chrystusa ${ }^{7}$. Jezus jest antytezą wszystkiego, do czego dążą Polacy, a jego etyka zakłamuje to, co Hempel nazwał "polskim duchem”. Dla Hempla Jezus Chrystus nie jest prawdziwym Bogiem, a kolejnym bożkiem, który odwodzi go od prawdziwej wiary. Wspólne dla romantycznego wieszcza i jego późniejszego naśladowcy jest jednak przekonanie o szczególnie uprzywilejowanej roli narodu polskiego w historii świata. Obaj autorzy podkreślają również, że naród polski pozostaje w uśpieniu i musi się dopiero przebudzić do właściwego działania. Wydaje się, że celem Kazań Hempla jest właśnie wytrącenie Polaków z marazmu, w jakim żyją. Najprawdopodobniej liczy on, że pod wpływem jego tekstów zostaną odrzucone kajdany religii chrześcijańskiej, a Polacy poprowadzą Europę ku prawdziwej Wolności. Cel Kazań jest zatem taki sam, jak ten obrany przez Adama Mickiewicza.

Wśród autorów, do których odwołuje się Hempel, są przede wszystkim inni polscy romantycy, jak Słowacki i Krasiński, ale również neoromantycy, jak Miciński. Szczególnie część idei wywodzących się z twórczości tego ostatniego autora - odnoszących się głównie do idei nadczłowieka i uprzywilejowania części ludzi - wydaje się zbliżona do koncepcji „Jana Bożego”.

Natomiast filozofem, z którego spuścizny - jak się wydaje - Jan Hempel korzystał, ale którego nie wymienił, jest Fryderyk Nietzsche. W Kazaniach bez trudu można znaleźć wiele odniesień do koncepcji zawartych w Woli mocy, Z genealogii moralności czy też Tako rzecze Zaratustra. Czytając Kazania, trudno jednak oprzeć się wrażeniu, że koncepcje Hempla są niezwykle podobne do idei zawartych w tekstach Nietzschego. Wydaje się wręcz,

${ }^{6}$ „I dał Bóg królom polskim i rycerzom Wolności, iż wszyscy nazywali się bracią, i najbogatsi, i najubożsi. A takiej Wolności nie było nigdy przedtem. Ale potem będzie." A. Mickiewicz, Księgi narodu polskiego i pielgrzymstwa polskiego, Toledo (Ohio) 1905, s. 26.

${ }^{7}$ Cytatów potwierdzających ową koncepcję można znaleźć bardzo wiele, np.: „I wokół Polski ugrupowały się trzy najciemniejsze mocarstwa, trzy najmocniejsze podpory Boga i wszelkiego duszącego prawa. A celem ich głównym jest walka z Polską, walka z wolnością, walka z liberum veto, które podnosząc się grozi ich tronom i ich prawom. Już to prawdziwa trójca boska w trzech państwach, ale - jak jeden Bóg - zgodna w przeciwpolskim działaniu." J. Hempel, Kazania polskie, s. 86. 
że Hempel starał się dokonać polskiej interpretacji myśli niemieckiego filozofa i uzupełnić ją o myśl mesjanistyczną ${ }^{8}$. Trudno jednak jednoznacznie ocenić, na ile był to tylko wpływ wcześniejszych lektur ${ }^{9}$, a na ile świadome działanie. Ustalenie precyzyjnej relacji między myślą Jana Hempla a filozofią Fryderyka Nietzschego wymaga dokładniejszego zbadania, którego tutaj się nie podejmuję.

Podobne problemy napotykamy przy próbie sformułowania jednoznacznych sądów na temat relacji między stanowiskiem Jana Hempla a modernizmem katolickim. Tekstem, w którym Hempel najpełniej ustosunkował się do tego prądu intelektualnego, był artykuł poświęcony książce Ignacego Radlińskiego pt. Katolicyzm, modernizm i myśl wolna ${ }^{10}$, w którym wyrażał się z wielką aprobatą o Alfredzie Loisym, uważając go za człowieka szczerego i rozumnego ${ }^{11}$. Szczególnie istotne dla Hempla było krytyczne podejście do chrześcijaństwa jako religii $\mathrm{w}$ formie zinstytucjonalizowanej ${ }^{12}$. $\mathrm{Na}$ pewno na aprobatę ze strony Hempla zasługiwało indywidualne podejście do wiary głoszone przez katolickich modernistów, zdaje się jednak, że ten prąd nie odgrywał istotnej roli w formowaniu się jego koncepcji antropologicznych, a jedynie momentami wydawał się zbieżny z jego myślą.

Hempel nie był jedynym autorem, który przedstawiał koncepcje anarchistyczno-nacjonalistyczne ${ }^{13}$. Jego poglądy popierał między innymi krakowski działacz Janisław Jastrzębowski, autor takich książek jak: Precz $z$ obłuda $w$ domu i w szkole!: kilka uwag w sprawie "religijno-narodowego" wychowywa-

\footnotetext{
${ }^{8}$ Jako jeden z licznych przykładów podobieństwa między antychrystianizmem Hempla a myślą Nietzschego może posłużyć chociażby następujący cytat: „Tak postępował w dalszym ciągu; w okresie moralnej idiosynkrazji swoich wysokich i wzniosłych stanów moralnych nie tłumaczył on jako wyniku swej woli jako »dzieła osobistego. Chrześcijanin także własną swą osobę rozkłada na lichą i słabą fikcyę, którą nazywa człowiekiem, i na drugą, którą nazywa Bogiem (odkupicielem, zbawicielem)”. F. Nietzsche, Wola mocy, przeł. S. Frycz i K. Drzewiecki, J. Mortkowicz, Warszawa 1911, s. 98.

${ }^{9}$ Podobnie traktuje rolę Nietzschego w myśli Hempla Jan Szmyd. Por. Jan Hempel - idee i wartości, s. 18 i s. 137.

${ }^{10}$ J. Hempel, Katolicyzm, modernizm i myśl wolna, „Krytyka”, t. 37, 1913, s. 264-268.

${ }^{11}$ Tamże, s. 267.

${ }^{12}$ Por. J. Szmyd, Jan Hempel - idee i wartości, s. 26.

${ }^{13}$ Szerzej o inspiracjach anarchistycznych pisał Jan Szmyd w swoim artykule pt. Praktyka i światopogląd. Próba rekonstrukcji światopoglądowej i ideowej Jana Hempla, „Studia Filozoficzne", 1969, nr 5, s. 15-47.
} 
nia młodzieży polskiej dla inteligentnych rodziców i postępowych pedagogów $w^{14}$, Precz z mięsożerstwem!: praktyczne wskazówki dla naszych postępowców do wyzyskania drożyzny mięsa w celu duchowego odrodzenia narodu polskiego ${ }^{15}$, do których Hempel napisał wstęp. Niemniej od większości anarchistów różnił się właśnie kontekstem mesjanistycznym i nacjonalistycznym. Największy z polskich działaczy anarchistycznych, Jan Machejski, czynnie występował zarówno przeciwko państwu, jak i inteligentom, którzy je tworzą. Tymczasem anarchizm Hempla nie był skierowany przeciwko porządkowi politycznemu, a przeciwko porządkowi etycznemu, który - jego zdaniem - był znacznie groźniejszy.

\section{Pan, czyli Ja}

W Kazaniach Jan Hempel jednoznacznie wskazuje na antropocentryczny model interpretacji świata. Człowieka stawia w centrum swoich rozważań i właśnie on będzie dla niego punktem odniesienia. Już w pierwszym rozdziale pism anarchistycznych zwraca uwagę na dwie idee konieczne do pełnej interpretacji fenomenu, jakim jest człowiek. Pierwszym jest Życie rozumiane jako energia, która przenika wszystkie istoty, oraz siła sprawcza dla wszelkiego działania, drugim zaś - dualizm, czyli podział na rzeczywistość ciała i rzeczywistość ducha ${ }^{16}$.

Człowiek wywodzi się z przesilenia ziemi, czyli - jak można domniemywać na podstawie tekstów Hempla - powstaje w wyniku ewolucji ${ }^{17}$. Oznacza to, że jego istnienie jest całkowicie niezależne od bogów czy też Boga. Początkowo jego egzystencja nie różni się niczym od egzystencji zwierząt ${ }^{18}$. Człowiek nie jest w stanie żyć w pełni, dopóki nie pozna religii, czyli świadomej afirmacji życia poprzez jego kontemplację w rytuale religijnym. Zdaniem Hempla, to właśnie powtarzanie czynności, które nie mają na celu ani zdobywania jedze-

\footnotetext{
${ }^{14} \mathrm{~J}$. Jastrzębowski, Precz z obłuda $w$ domu i w szkole!: kilka uwag w sprawie „religijno-narodowego" wychowywania młodzieży polskiej dla inteligentnych rodziców i postępowych pedagogów, Kraków 1906.

${ }^{15} \mathrm{~J}$. Jastrzębowski, Precz z mięsożerstwem!: praktyczne wskazówki dla naszych postępowców do wyzyskania drożyzny mięsa w celu duchowego odrodzenia narodu polskiego, Kraków 1910.

${ }^{16} \mathrm{~J}$. Hempel, Kazania polskie, s. 7, 13.

${ }^{17}$ J. Szmyd, Jan Hempel - Idee i wartości, s. 44.

${ }^{18}$ J. Hempel, Kazania polskie, s. 3.
} 
nia, ani płodzenia potomstwa, jest tym, co odróżnia ludzi od zwierząt - jest to bowiem idealna manifestacja życia jako takiego. W religii Człowiek odkrywa swoje powołanie do rządzenia światem ${ }^{19}$. Hempel stara się od samego początku stworzyć formę świeckiej religii - pozbawionej boga, ale opierającej się na pewnych obrzędach ${ }^{20}$.

Rytuał religijny sprawia, że Homo sapiens przeradza się w Homo religians ${ }^{21}$ i odkrywa drugą płaszczyznę rzeczywistości, czyli sferę Ducha, wskutek czego zaczyna widzieć różnice między rzędną przyziemną, czyli sferą ciała, oraz rzędną odziemną, czyli właśnie sferą Ducha. Rozpoznaje również, że do tej pierwszej należy wszystko to, co świadczy o słabości człowieka: potrzeba pomocy, opieki, litości, ciepła dłoni. Do drugiej rzędnej należy natomiast siła, rozmach twórczy i płodna Tęsknota ${ }^{22}$.

Życie - pisane u Hempla zawsze wielką literą - należy do poziomu Ducha. To dzięki niemu człowiek jest w stanie działać i wzbijać się na wyżyny swoich umiejętności, których przejawem jest podporządkowanie sobie świata. Kluczowym, jak Hempel wielokrotnie wspominał, elementem religii jest modlitwa. Należny hołd Życiu oddaje się poprzez działanie, płodzenie, odkrywanie i tworzenie. Natomiast tym, co cielesne w człowieku i co sprawia, że pozostaje on bezsilny, jest Śmierć.

W historii świata istnieją dwa prądy, pomiędzy którymi panuje ciągłe napięcie. Człowiek jest zawieszony między Życiem i Śmiercią oraz Wolnością i Niewolą. Pierwszy prąd wywodzi się z Grecji i Indii, a swoją doskonałą formę znajduje w kulturze słowiańskiej, drugi - z Izraela oraz Babilonu i ewoluuje do myśli chrześcijańskiej²3.

\footnotetext{
19 Ten fragment myśli Hempla jest wyjątkowo niejasny. Teksty nie dają odpowiedzi, czy Bóg lub bogowie wywodzą się z bytów zwierzęcych i sami przeszli drogę od kultu religijnego do afirmacji życia, czy też są istotami zupełnie innego porządku, które zazdrośnie strzegą swojej władzy.

${ }^{20}$ J. Szmyd, Praktyka i światopogląd. Próba rekonstrukcji światopoglądowej i ideowej Jana Hempla, „Studia Filozoficzne”, 1969, nr 5, s. 25.

${ }^{21}$ J. Hempel, Kazania polskie, s. 2.

${ }^{22}$ Tamże, s. 7-8.

${ }^{23}$ J. Hempel, Kazania piastowe, Bielsk 1912, s. 205, oraz J. Szmyd, Etyka polska..., s. 102.
} 


\section{Bóg-ciemiężyciel}

Interpretacja wczesnych pism Jana Hempla bywa pod wieloma względami niełatwa. Autor pragnął, aby przekaz owych pism był jak najbardziej zbliżony do formuły tekstów religijnych, o czym świadczą już same tytuły: Kazania polskie i Kazania piastowe. Forma przedstawienia myśli w nich zawartej miała sprawiać wrażenie, że tekst jest natchniony, a autor jest rodzajem proroka albo mędrca. Konstrukcja przypomina sposób pisania przyjęty przez Fryderyka Nietzschego w Tako rzecze Zaratustra czy też wspomnianego już wcześniej Adama Mickiewicza z Ksiag narodu polskiego i pielgrzymstwa polskiego.

Przez swoich współczesnych Jan Hempel był dosyć często zwany „Janem Bożym", od jego zamiłowania do wchodzenia w polemikę z wszelkimi przejawami wiary w Boga. Ich krytyka odgrywała kluczową rolę w całym projekcie „etyki polskiej”, którą Jan Hempel pragnął stworzyć. Ten aspekt jego myśli jest szczególnie widoczny w pierwszym rozdziale Kazań polskich, czyli w Homo religians.

Niełatwo jednoznacznie wskazać, co Jan Hempel ma na myśli, kiedy mówi o Bogu. Można znaleźć passusy, w których z jednej strony mowa o tym, że to człowiek tworzy Boga poprzez swoje wyobrażenia ${ }^{24}$. Równocześnie pojawiają się fragmenty sugerujące, że Bóg jest tworem odwiecznym i nieskończonym. Zdaje się, że w tej kwestii Jan Hempel nie był w stanie dać jednoznaczniej odpowiedzi. Niemniej jednak wydaje się, że pomimo sprzecznych sądów Bóg jest zazwyczaj interpretowany jako byt realnie istniejący. Tym, co Hempel uważa za wyznacznikowe, jest kwestia relacji Człowieka z Bogiem i wynikające z tej relacji konsekwencje. Ludzie byli dla Hempla afirmacją Ducha, czyli tego, co najistotniejsze w całej rzeczywistości. Tymczasem Bóg ma nie pozwalać, żeby Człowiek mógł afirmować swoje Życie. Jak pisał Hempel: „Religia łączy człowieka z nadświatem. Bóg to alfa i omega, która doprowadza do skończoności człowieka, ogranicza go"25. Jego zdaniem tym, do czego powinien dążyć Człowiek, jest stworzenie religii wolnej od Boga ${ }^{26}$.

W tym miejscu myśl Jana Hempla wydaje się bardzo podobna do koncepcji prezentowanych przez Fryderyka Nietzschego w pismach krytykujących

\footnotetext{
${ }^{24}$ J. Hempel, Kazania polskie, s. 10.

${ }^{25}$ Tamże, s. 13-14.

${ }^{26}$ J. Szmyd, Praktyka i światopogląd. Próba rekonstrukcji światopogladowej i ideowej Jana Hempla, „Studia Filozoficzne”, 1969, nr 5, s. 25-26.
} 
chrześcijaństwo. Hempel - podobnie jak autor Tako rzecze Zaratustra - upatruje największego wroga człowieka właśnie w Chrystusie. Zgodnie z jego koncepcją to właśnie Jezus Chrystus sprowadził na świat śmierć poprzez podniesienie do rangi cnoty wszystkiego, co należy do rzędu przyziemnego.

W Kazaniach polskich Hempel analizuje z punktu widzenia krytyki religii dwie (jego zdaniem kluczowe) wykładnie chrześcijaństwa - Kazanie na górze oraz Ojcze nasz. Na ich przykładzie stara się wykazać, w jaki sposób z ich pomocą chrześcijaństwo zakłamuje faktyczną istotę człowieka ${ }^{27}$.

W przypadku modlitwy Ojcze nasz Hempel stara się wykazać, że już samo nazwanie Boga Ojcem niesie za sobą manipulacje ${ }^{28}$ - ustawia bowiem człowieka w relacji podrzędności w stosunku do Boga. Jego zdaniem już samo użycie słowa ojciec powoduje, że człowiek chce się udać do niego ze swoimi problemami oraz - że jest jak dziecko we mgle, które nie potrafi samodzielnie działać i potrzebuje pomocy. Na kartach rozdziału zatytułowanego Jezus Chrystus autor demaskuje kolejne fragmenty modlitwy. I tak na przykład werset „Przyjdź królestwo Twoje” interpretuje w następujący sposób:

Jeśli będziesz, jak pies, lizał bijącą cię rękę pana, jeśli poddasz nie tylko wszystkie uczynki, ale i wszystkie myśli swoje, jeśli dla niego wyrzeczesz się Życia radości wszystkie, w końcu gdy całkowicie ducha zabijesz w sobie i nie będzie już $\mathrm{w}$ tobie ani odrobiny twórczej mocy wówczas dostaniesz nagrodę, prawdziwie godnej ciebie i godnej tego, kto ci ją daje - Oto dane ci będzie przez wieczność całą patrzeć w kamienne oblicze twego pana i władcy i śpiewać hymn na cześć niewzruszonego ${ }^{29}$.

W podobny sposób Jan Hempel interpretował Kazanie na górze, w którym - jego zdaniem - zostały wyłożone zasady, którymi nie powinno kierować się w życiu. Osiem błogosławieństw jest tak naprawdę wykładnią słabości człowieka, Jezus Chrystus zaś podał je specjalnie, aby nie dopuścić człowieka do Życia i skazać go na Śmierć. Poprzez bycie pokornym, cichym i biednym afirmuje się skończoność rozumianą jako śmiertelność.

Słabość podniesiona do rangi cnoty skazuje na zagładę ludzi silnych, wszystkich tych, którzy nie chcą się poddać dyktaturze chrześcijaństwa. Chrystus poprzez Kazanie na górze miał stworzyć armię niewolników, którzy będą poddawali się jego woli i odwracali się od Życia. Na przykład formułę

\footnotetext{
27 Tamże, s. 22-23.

${ }^{28}$ J. Hempel, Kazania piastowe, s. 10.

${ }^{29}$ J. Hempel, Kazania polskie, s. 25.
} 
„błogosławieni cisi” rozumie Jan Hempel jako nienawiść Boga do chęci działania ludzkiego, gdyż:

Ojciec niebieski zazdrosny jest tak, jak jest wschodni despota: on nie znosi wokół siebie rozgwaru życia raźno płynącego, on jest nieprzyjacielem gromkich słów, żywych proszeń, oczu żaru pełnych albowiem drży o całość swojego panowania; on lubi jedynie cichych, bladych, jak cienie snujących się ludzi, o muskułach osłabłych, oczach zamglonych, w ziemię spuszczonych lub martwo zapatrzonych w krzyż - godło męczeńskiej śmierci ${ }^{30}$.

Relacja Boga z ludźmi przybiera formę walki. Szczególnie na podstawie pierwszych rozdziałów Kazań polskich można wysnuć pogląd, że Hempel rozumie ją wręcz jako walkę klas. Bóg jest Panem, burżujem, który uciska proletariat, czyli ludzi ${ }^{31}$. Zadaniem ludzi, którzy powinni stanąć w obronie Życia, jest rewolucja przeciwko Bogu - zdetronizowanie jego miejsca w świecie i jako lud zajęcie jego miejsca. Człowiek powinien - zdaniem Hempla kierować się w życiu jednym przykazaniem: „Nie będę miał bogów cudzych przede mną". Panem jestem Ja, czyli człowiek, nie zaś Bóg, który uzurpuje sobie władzę nad człowiekiem i światem.

\section{Polska Antychrystem narodów}

Wizja miejsca Polski w świecie zajmuje centralne miejsce w twórczości Jana Hempla z okresu anarchistycznego. W przypadku tego zagadnienia myśl autora Kazań polskich jest dosyć przejrzysta - Polacy mają do spełnienia specjalną rolę w historii świata. Ich celem, do którego są niemalże predystynowani, jest opowiedzenie się po stronie Życia i zwyciężenie Boga, a co za tym idzie - pokonanie Śmierci.

Wyraźnie widać w nich związek z romantyczną myślą mesjanistyczną. Polacy ${ }^{32}$ są narodem wybranym, który jako jedyny jest w stanie przeciwstawić się sile niepozwalającej ludziom na ich pełny rozwój.

\footnotetext{
${ }^{30}$ Tamże, s. 31.

${ }^{31}$ Owe sformułowania nie padają w tekście bezpośrednio. Hempel wspomina natomiast o panach, niewolnikach i o buncie.

${ }^{32}$ W przypadku Kazań piastowych Hempel zastępuje Polaków Słowianami. Najprawdopodobniej zabieg ten miał na celu zwiększenie ewentualnych odbiorców jego dzieła o przedstawicieli
} 
Recepcja dziejów Polski u Jana Hempla wydaje się podobna do tej, którą zaprezentował Adam Mickiewicz. Polska nie jest jednak Chrystusem narodów, a Antychrystem narodów. Jak sam pisał: „Zrobić z Polaka chrześcijanina to zabić w nim Polskę"33. Podobnie jak w koncepcji zaprezentowanej przez autora Ksiag narodu polskiego i pielgrzymstwa polskiego Polacy są narodem wybranym, który odgrywa specjalną rolę w dziejach całego świata. O ile w interpretacji Mickiewicza rozbiory Polski były przykładem tego, jak Polacy cierpią za cały świat, o tyle u Hempla było to wynikiem przyjęcia chrześcijaństwa i potwierdzeniem jego destrukcyjności.

Historiozofia Hempla zaczyna się u zarania dziejów Polski, kiedy była ona silnym i prężnym bytem, w którym płynęło Życie, dopóki nie została skolonizowana przez myśl semicką zakamuflowaną pod postacią chrześcijaństwa. Jego koncepcja wydaje się zbliżona do wizji świata prezentowanej przez współczesne ruchy neopogańskie, które utrzymują, że chrześcijaństwo jest tworem narzuconym prawdziwej naturze Polan.

Dotykamy tutaj istotniej kwestii wiążącej się ze sformułowaną przez Hempla koncepcją dwóch sił, które walczą o władzę nad światem: słowiańskiej i semickiej. Antysemityzm będzie dosyć często przewijał się na kartach zarówno Kazań polskich, jak i Kazań piastowych ${ }^{34}$. Żydzi są manifestacją sił, które dążą do zniszczenia Życia, a co za tym idzie - również Polski i Polaków. O ile w komunistycznym okresie twórczości Jana Hempla wątek antysemicki zniknął, o tyle w czasie anarchistycznym jest wyraźny. Możliwe, że powodem takiego stanu rzeczy była przemiana poglądów Hempla z nacjonalistycznych na internacjonalistyczne i ostateczne odejście od anarchizmu na rzecz komunizmu. Cechą charakterystyczną myśli Jana Hempla była znacząca ewolucja, która dotyczyła nie tylko jego myśli filozoficznej, ale również teorii stosunków społecznych i spraw osobistych. Jeżeli porównać jego pisma z pierwszych lat $\mathrm{XX}$ wieku z pracą Komuny rolne $w$ Z.S.R.R., widać, że przeszedł on daleką drogę od mistycyzmu do marksizmu-materializmu.

Kiedy żydzi pod pozorem chrystianizacji narzucili Polakom kult Chrystusa, czyli Śmierć, rozpoczął się regres w dziejach Polski. Z wieku na wiek

innych nacji. Dokładna lektura kontynuacji Kazań polskich jednoznacznie wskazuje, że kwintesencją Słowiańszczyzny są Piastowie, czyli założyciele państwa polskiego. Można zatem przypisać Hemplowi konsekwencję w tej kwestii.

${ }^{33}$ J. Hempel, Kazania polskie, s. 56.

${ }^{34}$ Informacja w pierwszym wydaniu Kazań polskich brzmi: „Drukować ukończono 19 stycznia roku panowania żydowskiego 1907”. 
Rzeczpospolita traciła na znaczeniu, coraz bardziej pogrążając się w kulcie, który doprowadził ją do ostatecznego upadku.

Jednak właściwa Polakom chęć afirmacji Życia była (i - zdaniem Hempla - jest) niewyczerpana i nieskończona. Na przestrzeni historii Polski wielokrotnie ujawniał się ten zwrot ku Życiu, a jako najważniejsze należy wskazać przede wszystkim niesławne liberum veto, które zdaniem autora Kazañ ${ }^{35}$ było właśnie przejawem afirmacji Życia.

Liberum veto było dla Hempla jawnym buntem przeciwko wszelkiego rodzaju narzuconym prawom. Zgodnie z jego wywodem miało ono być potwierdzeniem wielkości Polaków. Wolny sprzeciw był jedynym i najdoskonalszym z polskich praw. Dlaczego? Ponieważ właśnie w nim przejawia się Życie jako nieokiełznana energia:

Polska - to wulkan wiecznie wybuchający.

Polska - to wiosna, rwąca pęta lodów i do nowego wstępująca Życia.

Polska - to rewolucja nigdy nie cichnąca.

Polska - to młode Życie, z młodzieńczym rozmachem na świat wchodzące.

A prawo?

Prawo - to uczynek unieruchomiony w zwyczaju

Prawo - to zwyczaj skamieniały

Prawo - to pęta

Prawo - to kajdany na rozmach życia nałożone.

Jam jest wolność - powiedziała Polska.

Jam jest kamień okamieniający - mówiło prawo.

Czy mogła być między nimi zgoda ${ }^{36}$.

Konflikt między jakimkolwiek ustanowionym prawem a Polakami wydaje się zatem całkowicie zrozumiały. Wyraźnie przebijają tutaj przez myśl Hempla jego inklinacje anarchistyczne, które nakazują mu odrzucenie skodyfikowanego systemu państwa i administracji oraz systemu prawnego. W przypadku autora Kazań widać, w jaki sposób próbuje on wyciągnąć myśl anarchistyczną z przesłanek metafizycznych i historiozoficznych. Zarówno państwo jako twór polityczny, jak i prawo jako system regulujący należy odrzucić, ponieważ są one tworem żydowskim, przejawem kultu Śmierci, nie zaś kultu Życia, jak to jest w przypadku kultury Polaków (czy też po prostu Słowian).

\footnotetext{
${ }^{35}$ Tamże, s. 87.

${ }^{36}$ Tamże, s. 88.
} 
Doniosłość liberum veto, a co za tym idzie wszystkich Polaków, którzy je przyjmują za naczelną zasadę swoich działań polega na tym, że odrzucają wszystkie prawa, stawiają się ponad te nacje, które tworzą prawa, jak na przykład Anglicy ${ }^{37}$. Prawo jest bowiem wymysłem semitów, jako że powstało w Palestynie i ma na celu - tak samo jak wiara chrześcijańska - spętać wolnych ludzi.

Drugim przejawem polskiej wyjątkowości w historii świata jest konsekwentne stawanie po stronie Życia. W ten oto sposób czytelnik może wywnioskować z rozdziału Sobieski pod Wiedniem w Kazaniach polskich, że $\mathrm{w}$ gruncie rzeczy Sobieski walczył nie z muzułmanami, a z Chrystusem. Kiedy prowadził husarię do boju ${ }^{38}$, tak naprawdę był w religijnym uniesieniu i dokonywał afirmacji Życia. W tamtych czasach bowiem - zdaniem Hempla - Polacy mieli kierować się specyficznym systemem wartości zawartym w tak zwanej „modlitwie polskiej”:

Modlitwa polska - to Krakus zabijający smoka.

Modlitwa polska - to Kopernik wysadzający z posad ziemię i rzucający ją w wir przemian nieskończonych.

Modlitwa polska - to podanie ręki wrogiemu dotychczas narodowi i podniesienie go do godności brata.

Modlitwa polska - to obrona Życia jasnego przed nawałem mongolskiej nocy.

Modlitwa polska - to wolność polska.

Modlitwa polska - to Mickiewicza w samą twarz Boga spojrzenie ${ }^{39}$.

W modlitwie polskiej widać pewną zarysowującą się wyraźnie tendencję. Moralność polska, będąca afirmacją życia, charakteryzuje się męstwem (Krakus), działaniem w celu zmiany świata (Kopernik), kooperacją (podanie ręki wrogowi $)^{40}$, obroną idei wolności (obrona Życia i wolność polska) oraz dumą i bezkompromisowością (spojrzenie w twarz Bogu). Zgodnie $\mathrm{z}$ wykładnią przedstawioną w modlitwie Polacy dzięki swoim cechom zajmują uprzywilejowane miejsce wśród innych narodów.

\footnotetext{
37 Tamże, s. 88-89.

${ }^{38}$ Tamże, s. 45.

${ }^{39}$ Tamże, s. 53.

${ }^{40}$ Być może właśnie w tym passusie znajduje się przyczynek do późniejszych, komunistycznych poglądów Hempla. Współpraca dla dobra ogółu ponad podziałami miała w późniejszym okresie stać się istotnym elementem w myśli Hempla.
} 
Na przykładzie modlitwy Hempla można prześledzić, ku jakiemu projektowi społecznemu zmierza koncepcja autora. Na ostateczną formę „modlitwy polskiej" miały wpływ wolnomyślicielskie poglądy Hempla i jego pragnienie uwolnienia się od pęt wiary w Boga. Odrzucenie Boga nie oznacza odrzucenia religii, o czym wyraźnie pisał w pierwszym rozdziale Kazań polskich. Skoro religia jest najwyższym przejawem Życia człowieka, Jan Hempel chce stworzyć religię polską, będącą afirmacją Życia, czyli działania i nieograniczonej przez prawa wolności.

Nie przypadkiem Hempel przywołał w „modlitwie polskiej” autora Dziadów. W jego interpretacji Adam Mickiewicz w historii Polski odgrywa niezwykle istotną rolę, na co Hempel wskazuje zarówno w Kazaniach polskich, jak i w Kazaniach piastowych. Nie jest to jednak faktyczna myśl Mickiewicza, a jego interpretacje dokonane przez Hempla. Pierwsze wzmianki o Mickiewiczu czytelnik może znaleźć w Kazaniach polskich, gdy Hempel wymienia autora Dziadów jako jednego z nielicznych ludzi w historii, którzy przeciwstawili się Bogu i uwolnili się z więzów chrześcijaństwa. Był on „orłem myśli Ducha” i razem z Norwidem, Słowackim i Krasińskim byliby największymi spośród twórców, gdyby nie ciążył na nich „ciężar krzyża”" to właśnie romantycy trafili na ślad prawdy. Na przykład Zygmunt Krasiński słusznie odkrył, że nie wolno czcić Boga jako Ojca, ale należy go czcić jako Pana, który jest afirmacją Życia ${ }^{42}$. Nie odkrył tylko tego, co odkrył dopiero Hempel - że prawdziwym Panem jest Człowiek ${ }^{43}$. Równocześnie romantycy, a szczególnie Mickiewicz, odkryli również, jaki jest cel Polski:

Świadomość tego, że walka za zbawienie świata jest naszą pospolitą rzeczą, do pełni w Mickiewiczu dochodzi. - Stąd Legjon - powstaje, przedziwny ów Legjon co jasno i z radością szczerą powiedział sobie: - idę na zbawienie świata! ${ }^{44}$.

Celem Kazań, co słusznie zauważył Szmyd ${ }^{45}$, było stworzenie kodeksu etyki polskiej, czyli zbioru zasad mających na celu uwolnienie Polski z więzów chrześcijaństwa. Celem ostatecznym było jednak uwolnienie całej ludzkości pod przewodnictwem Polaków (Słowian). Ostateczną misją jest zatem bycie antymesjaszem dla dziejów. I właśnie taka wizja została zarysowana w „mo-

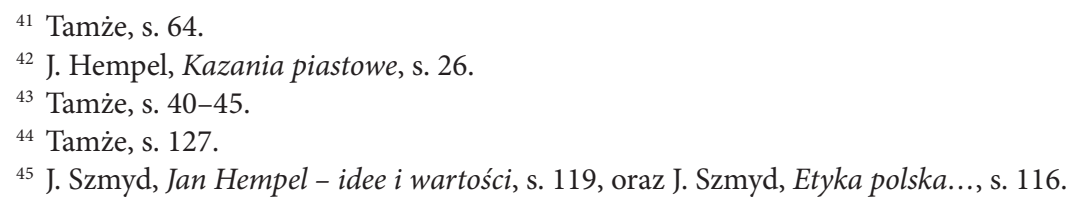


dlitwie polskiej”. Mesjasz jest bowiem afirmacją słabości, Polska tymczasem jest najdoskonalszym przejawem siły. Ma stać się ona Bohaterem, który zbawi ludzkość niczym Herkules i Prometeusz ${ }^{46}$.

Chrześcijaństwo doprowadziło do zagłady Polski, nie doprowadziło jednak do ostatecznej klęski Życia. Polacy zostali zgubieni, ponieważ przyjęli etykę chrześcijańską, co było celowym działaniem czczących Śmierć Semitów. Polska stała się ofiarą spisku, mającego na celu wykluczenie Życia. Cywilizacja Śmierci swoje ostrze skierowała właśnie przeciwko Polakom, ponieważ to właśnie oni w najdoskonalszy sposób przejawiali potęgę Ducha, chociażby dzięki liberum veto.

Dokładną historię spisku mającego na celu zniszczenie Polski i Polaków podał Jan Hempel na kartach ${ }^{47}$ Kazań piastowych w historii usidlenia poczciwego Piasta w etykę chrześcijańską. Stało się to, jak wskazuje autor, poprzez semickich wysłanników, czyli księży misjonarzy, którzy przynieśli Słowianom chrześcijaństwo.

\section{Jan Hempel mesjanista?}

Niezaprzeczalnie wizja, w której Polska ma specjalne posłannictwo w historii świata, odgrywała ważną rolę w myśli Jana Hempla. Polacy mieli odegrać w dziejach rolę Herkulesa-Piasta i stawać po stronie Życia, czyli być przeciwwagą dla semickiej tradycji kultu Śmierci. Polak jest najdoskonalszym przejawem Człowieka, czyli najwyższej afirmacji Życia, które z kolei jest przejawem Ducha ${ }^{48}$.

Polacy w przeciwieństwie do innych nacji wielokrotnie dali wyraz swojemu posłannictwu w afirmacji Życia. Pierwszym z nich była wiktoria wiedeńska, kiedy Jan Sobieski, prowadząc szarżę husarii, złożył najlepszy przykład afirmacji Życia. Drugim była instytucja liberum veto, w której Polacy jako jedyni w cywilizowanym świecie odrzucali sztuczne prawa i stawiali siebie ponad nimi, tym samym odrzucając Śmierć.

Obraz wyłaniający się z pism Jana Hempla jest jednak niejasny. Utrzymane w stylu tekstu religijnego pisma w wielu miejscach są nieprecyzyjne i we-

\footnotetext{
${ }^{46}$ J. Hempel, Kazania polskie, s. 227.

${ }^{47}$ Tamże, s. 79-80.

${ }^{48}$ J. Szmyd, Etyka polska..., s. 113.
} 
wnętrznie niespójne. Wydaje się, że szczególnie dyskusyjne jest powoływanie się autora na spuściznę Adama Mickiewicza i całkowite ignorowanie faktu, że w Mickiewiczowskiej koncepcji Polska miała być Chrystusem narodów właśnie dlatego, że wiele w swojej historii wycierpiała. Hempel tymczasem stoi na stanowisku, że Polska zaczęła cierpieć, ponieważ została Chrystusem narodów, co doprowadziło do jej upadku. Trudno również określić, w jakim stopniu na jego twórczość miał wpływ między innym August Cieszkowski i jego interpretacja Ojcze nasz. Z jednej strony mamy do czynienia ze zbieżnością tematów, z drugiej strony interpretacja modlitwy w wydaniu Hempla jest zupełnie inna. Sam Hempel nigdzie nie odnosi się do Cieszkowskiego i jego myśli. Tak samo jak nie odnosi się do innych prądów intelektualnych swojej epoki. Próżno w Kazaniach polskich i Kazaniach piastowych szukać odwołania na przykład do modernizmu katolickiego. Trudno nawet wyrokować, czy Hempel mógł znać prace myślicieli tego nurtu.

Chociaż pisma Hempla są niejasne i nastręczają licznych problemów interpretacyjnych, zasługują jednak na uważną lekturę. Skonstruowane przez Hempla interpretacje pokazują, jakimi torami biegły polskie rozmyślania o dziejach, szczególnie że jego koncepcja znacząco odbiega od większości analiz owych zagadnień.

\section{Bibliografia}

Arnold C., Mała historia modernizmu, Kraków 2009.

Hempel J., Katolicyzm, modernizm i myśl wolna, „Krytyka”, t. 37, 1913, z. V, s. 264-268 .

Hempel J., Kazania polskie, Toledo 1907.

Hempel J., Kazania Piastowe, Bielsk 1912.

Jastrzębowski J., Precz z obłuda $w$ domu i w szkole!: kilka uwag w sprawie „religijno-narodowego" wychowywania młodzieży polskiej dla inteligentnych rodziców i postępowych pedagogów, Kraków 1906.

Jastrzębowski J., Precz z mięsożerstwem!: praktyczne wskazówki dla naszych postępowców do wyzyskania drożyzny mięsa w celu duchowego odrodzenia narodu polskiego, Kraków 1910.

Mickiewicz A., Księgi narodu polskiego i pielgrzymstwa polskiego, Toledo (Ohio) 1905, s. 26.

Nietzsche F., Wola mocy, przeł. S. Frycz i K. Drzewiecki, J. Mortkowicz, Warszawa 1911. 
Polski słownik biograficzny, t. IX, Wrocław - Warszawa - Kraków 1960-1961.

Szmyd J., Etyka polska. Z wczesnych pogladów etycznych Jana Hempla,,Etyka”, 1973, nr 12, s. 95-123.

Szmyd J., Jan Hempel - idee i wartości, Warszawa 1975.

Szmyd J., Praktyka i światopoglad. Próba rekonstrukcji światopogladowej i ideowej Jana Hempla, „Studia Filozoficzne”, 1969, nr 5, s. 15-47.

\section{Abstract \\ Vision of the Historical role of Poland in Jan Hempel's Sermons}

The article presents the vision of the role of Polish nation presented in two works written by Jan Hempel - Polish Sermons and Piast Sermons. The main purpose of the article is to provide the reader with Hempel's reinterpretation of the role of Poles elaborated by the authors of the Romantic period who regarded Polish nation as the God's chosen people. Hempel, being a lifelong critic of Christianity, thought of Poland as the Antichrist of nations. With this view in mind he interpreted Polish history and the role of Polish nation in the history of world. Author of the article presents Hempel's vision of the aforementioned role of Polish nation and seeks its sources in the writings of other thinkers.

Key words: Jan Hempel, romanticism, anarchism, criticism of Christianity, messianism 